\title{
Mobility of Some High Persistent Organochlorine Compounds from Soil to Mentha Piperita
}

\author{
DIANA PUIU ${ }^{1,2 *}$, MARIANA POPESCU1,3, MARCELA NICULESCU ${ }^{1}$, LUOANA FLORENTINA PASCU ${ }^{1}$, TOMA GALAON ${ }^{1}$, \\ CARMEN POSTOLACHE ${ }^{2}$ \\ ${ }^{1}$ National Research and Development Institute for Industrial Ecology, INCD ECOIND Bucuresti, $71-73$ Drumul Podul \\ Dambovitei Str., 060652, Bucharest, Romania, \\ 2Faculty of Biology, University of Bucharest, Splaiul Independenei 91-95, 050095, Bucharest, Romania \\ ${ }^{3}$ Faculty of Pharmacy Titu Maiorescu, 22 Dambovnicului Str., Bucharest, Romania
}

\begin{abstract}
The fate of organochlorine compounds in soil ecosystem is shaped by their physical-chemical properties and by environmental conditions. The high persistence of polychlorobiphenyls (PCBs) in soil is given by a slow degradation which varies from months to years (the half-life of PCB 28 is 10.9 years, and PCB 52, 11.2 years). Due to high lipophilicity, these carcinogenic compounds can be easily uptaken by plants and transferred to the food chain. The widespread use of medicinal plant, Mentha Piperita, in pharmaceutical and food industry represents a risk of contamination and pollution. Through laboratory studies, we worked to identify the chemical behavior in soil and plants of some PCB congeners: 28, 52, 138, 153 and 180). The compounds mobility from soil to the roots and then through plant was monitored for 5 weeks. By optimizing the analytical method the contaminants were determined from soil and plant with good recoveries and with reduced limit of detection, below $0.01 \mathrm{mg} / \mathrm{kg}$. It was reported that usually are uptaken into the plant high chlorinated PCBs like PCB 153 and $P C B 180$ but this study shows that after 5 weeks of $P C B$ application, the concentration of $P C B$ 28, a trichlorobiphenyl, is increasing. Fortunately, calculating the bioconcentration factor (BCF) of the selected PCBs in roots, it was shown that is similar to BCF of other plants like poplar and zucchini. The obtained value of 0.2 is assessed as being low.
\end{abstract}

Keywords: bioconcentration factor, medicinal plants, Mentha Piperita, PCB

The concern of soil pollution with persistent organic and inorganic contaminants is still a current issue due to environmental impact on soil quality [1-3] and food webs. The use of persistent organic pollutants (POP), which are the most known organic pollutants, is banned in the EU through the Stockholm Convention on POP in 2001 [4] because of their persistence in water and soil (half-life more than 10 years), toxicity (carcinogenic to humans), high dispersion (even in Tibetan Plateau) and bioaccumulation in aquatic organisms [5]. The contaminants are removed from soils using physicalchemical technologies or through bioremediation processes. The second one can be classified as: transfer process in other environment compartments (through volatilization, air wet deposition, water run-off, irrigation or by up taking into the plants through the roots), abiotic degradation process like oxidation, dehalogenation or dehydrogenation, and biotic degradation [6-8]. The hydrophobic nature of polychlorinated biphenyls (PCBS), one class of the first 12 POPs, is responsible for compounds immobilization on the soil surface, but organic acids and plant-derived sugars act as a surfactant which favors the uptake of PCBs into plant tissue or their biodegradation [9].

The PCBs present in plant cells are metabolized via enzymatic processes (with mono and dioxygenase, dehydrogenase, hydrolase, peroxidase, nitroreductase, dehalogenase, phosphatase or carboxilesterase) in compounds as other PCBs, or in stable and toxic metabolites as hydroxy-PCBs (OH-PCBs), PCB-epoxide, PCB-catechol and PCB-methylsulfonate, which can damage the biological processes of the plant [10]. Butthese slow processes indicate a source of contamination for food, vegetables and medicinal herbs, primary products which facilitates the route of pollutants to human and animal organism [11]. Comparing to herbals, in soils PCBs follow a slow metabolic degradation (which means high persistence), mainly based on complex interactions with biofilm generated by microorganisms present in root soil, which consists of bacteria and inorganic structures [12]. The specific microorganisms which degrade PCBs are gram positive and negative bacteria from species like Achromobacter, Acinetobacter, Alcaligenes, Pseudomonas, or Bacillus, Rhodococcus which, in the presence of plant phenolics, flavonoids or other compounds, increase the contaminant degradation rate [13]. Anyway, it was revealed that through biotic and abiotic soil conditions, PCBs are first degraded in corresponding chlorinated benzoic acid, chlorobenzoates and ring opening to chlorinated aliphatic acids, compounds which are then mineralized to $\mathrm{CO}_{2}$ and $\mathrm{H}_{2} \mathrm{O}$ [11].

The selected PCBs from the existing 209 congeners show a similar chlorine number position (Table 1 ) and differ from non-ortho-PCBswhich are called dioxin-like congeners due to same properties and toxicity, but bind strong to organic matter [14]. PCBs uptake into plants from soil (phytoextraction) represents a viable solution in depolluting affected soils, but also a risk of vegetation contamination due to plants ability to enhance the sorption through the roots of the organic compounds $[3,13]$.

The up taking of pollutants from soils to plants can be assessed by several factors. PCBs bioconcentration in roots is calculated with a bioconcentration root factor (RCF) which represents the ratio between pollutant concentrations quantified in dried roots and soil. In a similar way is calculated the bioconcentration factor in plants (BCF). Some authors developed equations to estimate the BCF in plants based on lipophilicity constant, Log $\mathrm{P}_{\text {ow }}$ [15]. The theoretical results are posted on Table 1.

The main methods used in organic contaminants determination are based on gas or liquid chromatography separation, where gas chromatography technique 


\begin{tabular}{|l|l|l|l|l|}
\hline \multicolumn{2}{|l|}{ Compound } & Log Pow $_{\text {ow }}$ & BCF & $\begin{array}{l}\text { bp } \\
{ }^{\circ} \mathbf{C} \text { at } \\
\mathbf{7 6 0} \mathbf{~ m m H g}\end{array}$ \\
\hline PCB 28 & $2,4,4^{\prime}$ trichlorobiphenyl & 5.61 & 17680 & 330.3 \\
\hline PCB 52 & $2,2^{\prime}, 5,5^{\prime}$ tetrachlorobiphenyl & 5.92 & 40670 & 344.9 \\
\hline PCB 138 & $2,2^{\prime}, 3,4,4^{\prime}, 5^{\prime}$ hexachlorobiphenyl & 6.78 & 67170 & 400.0 \\
\hline PCB 153 & $2,2^{\prime}, 4^{\prime}, 4^{\prime}, 5^{\prime}$ hexachlorobiphenyl & 6.83 & 25260 & 396.2 \\
\hline PCB 180 & $2,2^{\prime}, 3,4,4^{\prime}, 5^{\prime}, 5^{\prime}$ heptachlorobiphenyl & 7.16 & 4922 & 424.3 \\
\hline
\end{tabular}

Table 1

PHYSICAL AND CHEMICAL PROPERTIES OF THE SELECTED COMPOUNDS represents an optimal solution for determination of PCBs due to their lower boiling points (bp) $[6,7,16,17]$.

The aim of the current study consists in the assessment of the uptake of selected contaminants in Mentha Piperita roots, stem and leaves in 5 weeks of monitoring, in laboratory conditions.

\section{Experimental part \\ Chemicals}

The soil was contaminated with a mix of $10 \mathrm{mg} / \mathrm{L} \mathrm{PCB}$ (PCB 28, 52, 101, 138, 153, 180) in isooctane, from Supelco. Before analysis all samples were spiked with two internal standards: $100 \mathrm{mg} / \mathrm{L}$ PCB 209 in isooctane purchased from Dr. Ehrenstorfer, and solid pentachloronitrobenzene, analytical grade, purchased from Sigma Aldrich. The samples were extracted with solvents as Hexane $99 \%$ and acetone RESI which were acquired from J.T. Baker, and further the extracts were dried with anhydrous sodium sulfate which was purchased from Chimreactiv.

\section{Equipment}

All analyses were carried out using an Agilent 7890A gas chromatograph with an electron capture detector (GCECD). The injection mode was pulse splitted 1:5. The compounds from $1 \mu \mathrm{L}$ extract injection were separated through a fused-silica capillary column, HP-5MS (60 m, $0.25 \mathrm{~mm}$ I.D., $0.25 \mu \mathrm{m}$ f.d.), coated with $5 \%$ phenyl and 95 $\%$ dimethylsiloxane and carried out with helium at $1.2 \mathrm{~mL} /$ min flow rate. SSL inlet was kept at $280^{\circ} \mathrm{C}$ degrees. The oven temperature program starts from $50^{\circ} \mathrm{C}$ about $1 \mathrm{~min}$, increasing to $180^{\circ} \mathrm{C}$ with $20^{\circ} \mathrm{C} / \mathrm{min}$ rate, held $0.5 \mathrm{~min}$, then increases in $6 \mathrm{~min}$ to $240^{\circ} \mathrm{C}$ and hold for $4 \mathrm{~min}$, then stepup to $300^{\circ} \mathrm{C}$ by ramp of $14^{\circ} \mathrm{C} / \mathrm{min}$, held $9.5 \mathrm{~min}$; the total run time was $31.8 \mathrm{~min}$. The analytes were monitored by maintaining the ECD detector at $350^{\circ} \mathrm{C}$.
Samples preparation

Soils of 14 recipes of Mentha Piperita plants were treated with $5 \mathrm{mg} / \mathrm{L}$ mix of PCBs. For 5 weeks, plants grew in a closed space at constant temperature $20^{\circ} \mathrm{C}$, under normal light conditions (day / night 12/12). Duplicates of the dried and ground vegetal samples, root (0.8-3.8 g) and steam and leaves (0.4-1.5 g), were extracted $30 \mathrm{~min}$ through ultrasonication with $25 \mathrm{~mL}$ hexane and $15 \mathrm{~mL}$ acetone, while $10 \mathrm{~g}$ soil were extracted with $100 \mathrm{~mL}$ hexane : acetone $=1: 1$, as it is mentioned in the accredited standard, SR ISO 10382/2007 [18].

Due to the matrix loaded with various GC method interferences as hydro and liposoluble chemical compounds (carotenoids, polyphenolcarboxylic acids, flavonoids, volatile oils, etc.), it was necessary to purify the extract. Thus, a yield recovery of the compounds of interest was sought in 2 ways: by concentrating and passing of 5 $\mathrm{mL}$ of the extract through a $3 \mathrm{~g}$ alumina filled column or by reacting with $8 \mathrm{~mL}$ of $\mathrm{H}_{2} \mathrm{SO}_{4} 96 \%$.

\section{Results and discussions}

Purification of the extracts

Due to the high stability of PCBs molecules, the extracts could be easily treated with concentrated $\mathrm{H}_{2} \mathrm{SO}_{4}$, with high recoveries of PCBs and less interfering compounds which are degraded to smaller molecular mass compounds that are expected to be more polar. Unfortunately, the degree of mineralization of impurities with sulphuric acid waslow, while extract purification through alumina gave better results, higher recoveries and less interference resulted from the complex organic compound plant matrix, as it is shown in figure 1 .

Using alumina purification, the PCBs concentration from soils was determined with a limit of quantitation of 0.01 $\mathrm{mg} / \mathrm{kg}$, with $19.64 \%$ uncertainty. The peaks of the studied compounds are characterized by a Gaussian form, good
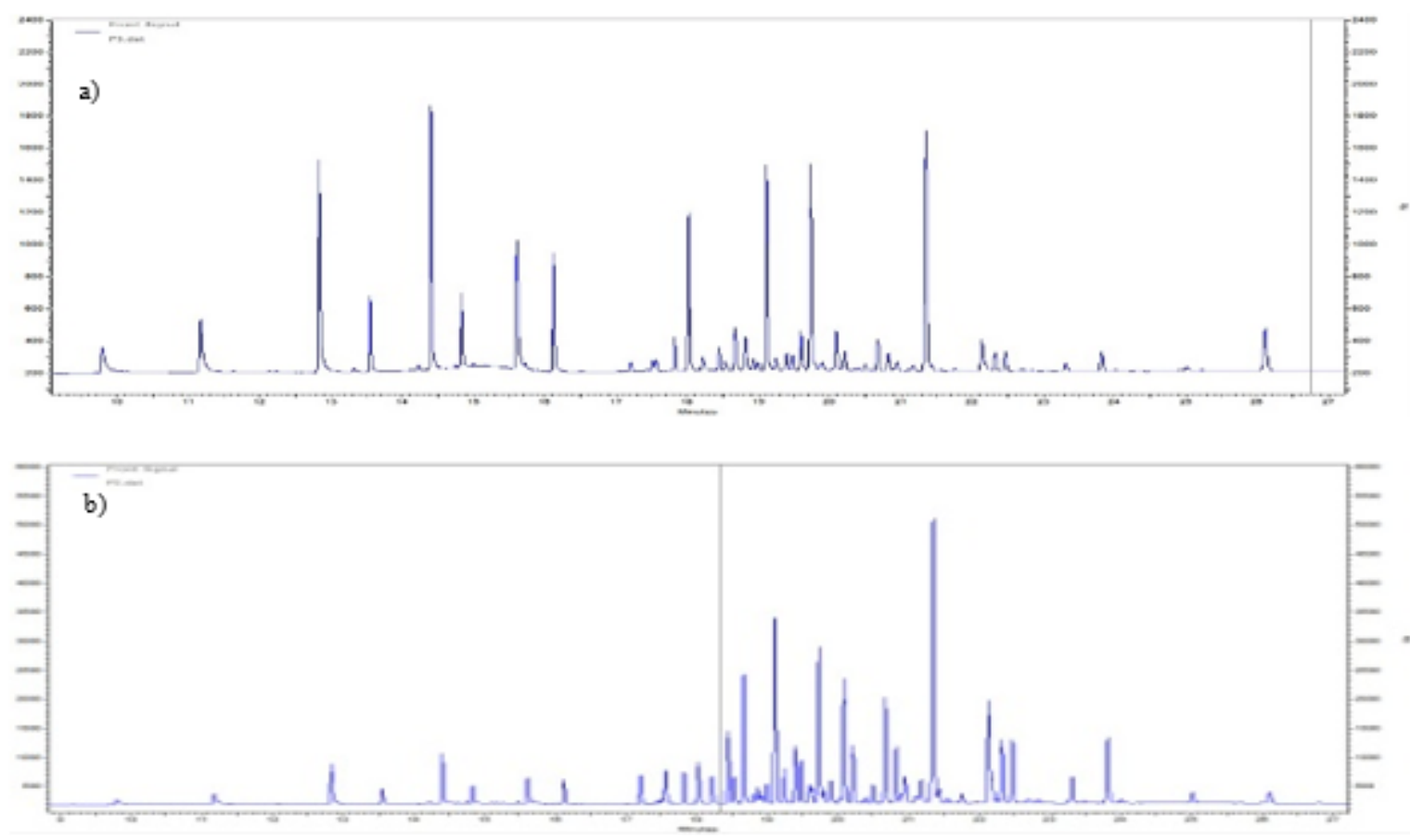

Fig. 1. Chromatograms of PCBs extract purified with a) basic alumina and b) $\mathrm{H}_{2} \mathrm{SO}_{4} 96 \%$ 
resolution and a signal-to-noise ratio greater than 10 for results quantified with values higher than $0.004 \mathrm{mg} / \mathrm{kg}$ for root, stem and leaves samples. The linear calibration used was in range between 5-200 $\mu \mathrm{g} / \mathrm{L}$. The soil used in the experiment was already contaminated with PCB 138, PCB 153 and PCB 180 which represent 29,42 and $59 \%$ from the applied doses, while in vegetable samples couldn't be detected the PCBs. The related values were removed from further data.

\section{Assessment of PCBs distribution in plant}

It was observed that during the experiment, the total amount of pollutants from roots has a rising allure with a maximum in the $4^{\text {th }}$ week, then followed by a decrease as it is seen in figure 2. However, the ratio of PCBs from stem and leaves to root is higher in the fifth week (t5), where the PCBs concentration of aboveground biomass represents $31 \%$ from the total contents of PCBs determined in the plant, which also indicates that the quantity of PCBs from upper plant tend to increase in time. This fact is influenced by concentration variation of the individual PCB linked to their physical chemical properties.

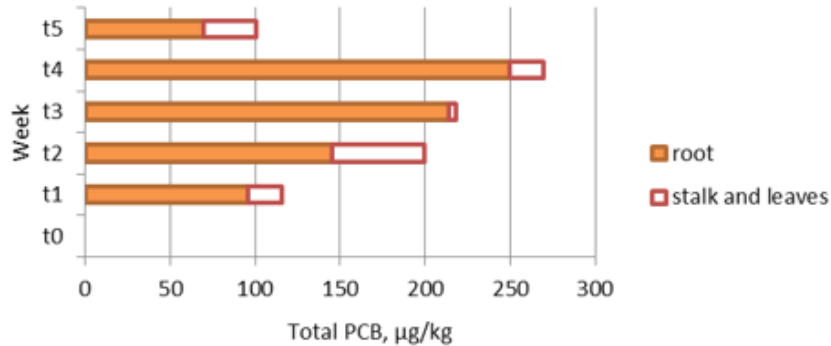

Fig. 2. Total concentration of PCBs from root and aerial part of the plant (stem and leaves) reported to dry mass of the sample, for every week

The most lipophilic compounds (table 1 ), the sum of PCB 180 and 153 congeners (hepta and hexachloro-byphenils), represents over $65 \%$ from the total amounts of PCBs determined in root, a constant value until the $5^{\text {th }}$ week when is decreased to $43 \%$. Also, at t5 PCB 28, a trichlorobyphenyl, increased to $44.5 \%$ (fig. 3), possibly due to dehalogenation processes which can generate lower chlorinated biphenyls. Anyway, the presence in high concentration of 153 and 180 congeners in Mentha Piperita biomass plant is contrary to European Food Safety Authority (EFSA) data where PCB 153 and PCB 138 represent plants PCBs profile. The mobility of PCB 153 could be favored due to its symmetrical structure [19].

According to the reported studies, it is expected that too low (Log Pow <1.5) or high lipophilic (Log Pow> 4) pollutants will not reach the upper part of the plant due to absorption into the root lipids or due to the inability to pass through the hydrophobic membrane cells [12], which explains the higher concentrations of PCBs in roots. Also, the concentrations of PCB 153 and PCB 180 have the same variation in time in leaf and stem samples, butPCB 28 was identified in higher concentration (fig. 3) since the first week. The percentage increase of PCB 28 during the experiment could be a result of herb lack of enzymes for degradation of low chlorinated compounds, because PCB 28 demands less energy to be degraded than more chlorinated biphenyls [20]. At all, a maximum of $3 \%$ from total content of PCBs from soil were quantified in upper parts of the plant, while a maximum of $6.3 \%$ was detected in roots (fig. 4).

It was observed that the variation of PCBs concentration in plants is not linear in time, mainly because the quantified concentration depends strongly on the size of the root surface and less of root mass. Higher quantity of roots, which weighted between 2.64-3.77 g for samples from $t 2$ and $t 4$, sorbed high quantity of PCBs, at least 2 times higher than the roots weighting 0.88-1.13 g. But relating these values to dry mass, the obtained results differ and are lower, which means that the take-up of the pollutant in the root does not depend directly on the root mass, but is related to root surface area. Some studies report that these lipophilic compounds will adhere strongly to the rootsurface without being absorbed into the plant $[12,18]$. This is applied especially to hexa and hepta chlorobiphenyls, which explain the increasing of PCB 153, 138 and 180 concentrations for the small amount of root (fig. 5).

\section{Assessment of PCBs phytoextraction}

As it is expected due to high persistence in soil of these contaminants, the PCBs sum concentration determined in soil is constant during the 5 weeks of experiment, with a standard deviation of $9.6 \%$ which is below the method uncertainty $19.6 \%$. This value shows that the uptake of PCBs in plant was too low to influence significantly the contaminants removal from soil.
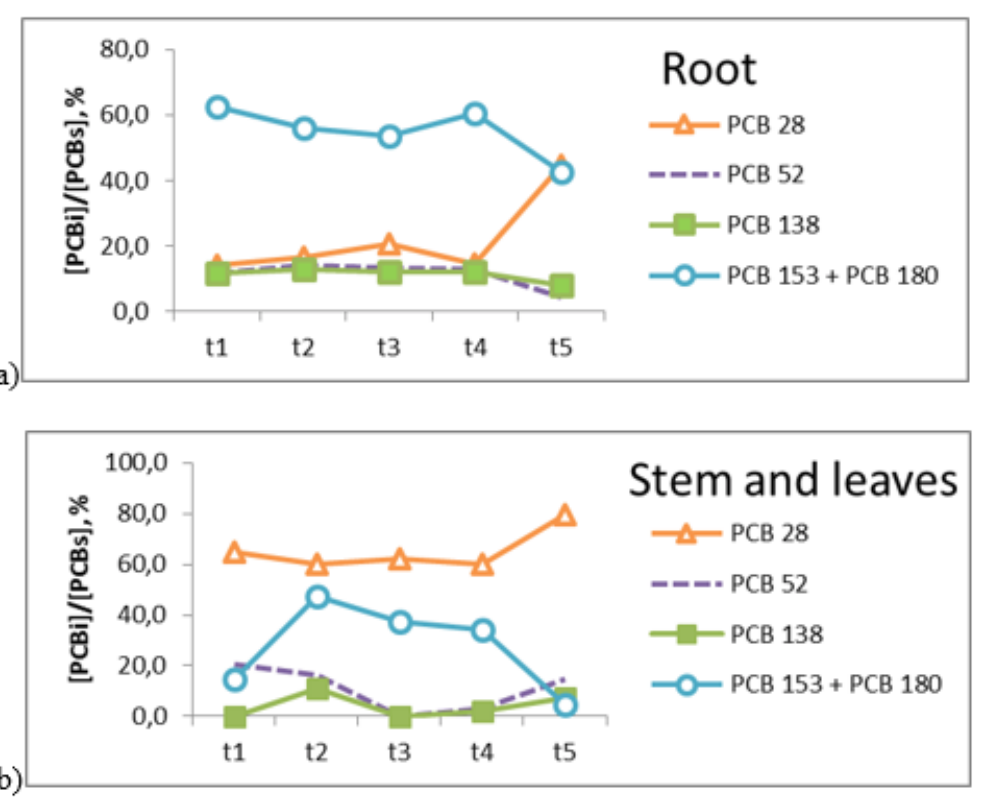

Fig. 3. Variation of PCBs in root (a), stem and leaves (b) as relative percentage from total PCBs content

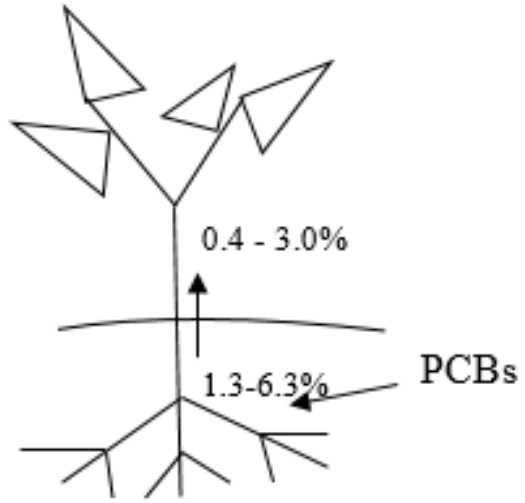

Fig. 4. Short representation of PCBs transport through plant 

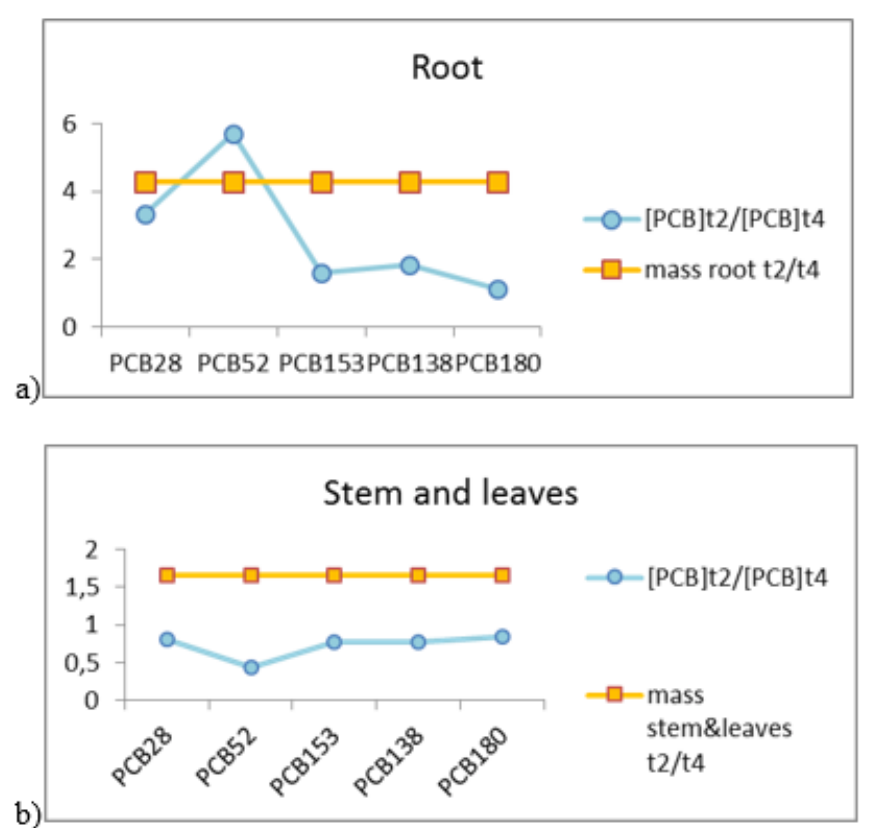

Fig. 5. The ratio between quantities of extracted pollutant from

$3.77 \mathrm{~g}$ and $0.88 \mathrm{~g}$ roots sampled in the $4^{\text {th }}$ week $(\mathrm{a}) ; 0.86 \mathrm{~g}$ si $0.50 \mathrm{~g}$ mix of stem and leaves sampled in the $2^{\text {nd }}$ week (b)

Similar to other garden herbs, mentha has large and stretched roots which favor the assimilation process. However, relating the total content of selected PCBs determined in whole plantto the added content in soil, the highest uptake was about $2.24 \%$, in the second week, as it is represented in figure 6 . The variation of contaminants uptake is function of root mass and surface, but tend to decrease during the experiment.

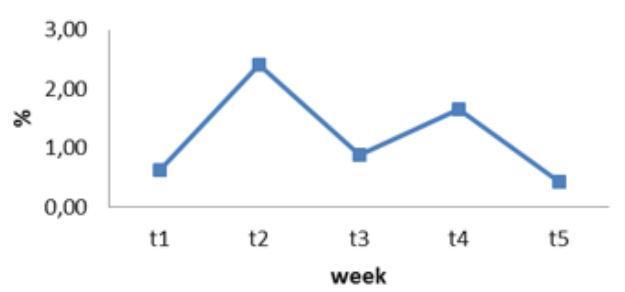

$-\%$ PCBs plant upta

Fig. 6. Percentage of total PCBs content (congeners 28, 52, 138, 153,180 ) determined in all plant (root, stem and leaves) reported to total PCBs content added into soil, without plant and soil mass

correction. The percentage is calculated for every week.

After 4 weeks monitoring, the calculated bioconcentration factor in the root (RCF - the ratio between concentration of the pollutant in the dry root and initial soil concentration) is about 0.2 for each PCB. This value is comparable to other bioconcentration factor values found in literature, like 0.1-0.5 for poplar, calculated for 420 days of contamination [17], or for roughs and zucchini after 10 weeks, with BCF for whole plant as 0.2 [3]. Other plants studied in literature were leguminous vegetables, weeds and grass but less medicinal herbs. Some comparative data are showed in figure 7.

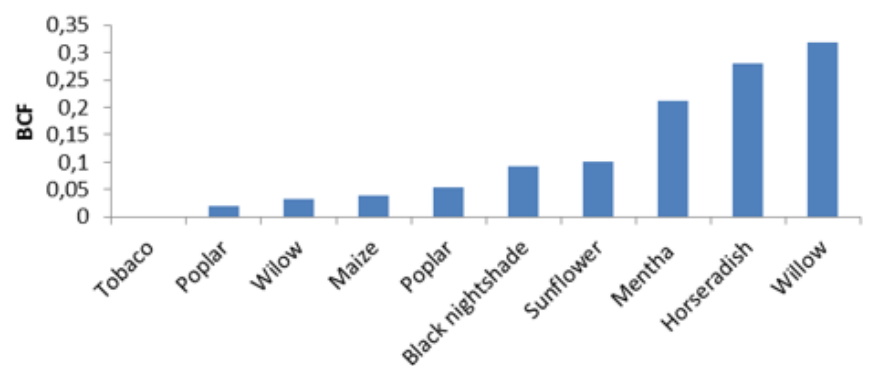

Fig. 7. The results for BCF found in literature for different plants [3, 21-23]
According to the criteria stated by the environmental organizations in Canada, a compound can be considered as bioaccumulative if BCF is higher than 5000 or Log Pow higher than 5, whereas in Europe the criteria drop to Log Pow higher than 4.5 and BCF higher than 2000 [24]. The results of this study are much lower than both criteria.

The high variation between the duplicate sample results is determined by a cumulus of factors that can influence the quality of the results obtained. Soil homogeneity and bioavailability of PCBs in soil, microorganisms, soil nutritional profile, water content, temperature, and other interactions can influence both the transfer of PCBs to the roots and their biodegradation. These factors cannot be fully controlled, but from an analytical point of view, there is space to improve extraction and purification method.

\section{Conclusions}

Polychlorinated biphenyls are a class of highly toxic compounds for human and animal organisms. Due to their stability in various environments (water, air, soil) and strong lipophilicity character, the compounds can easily insertinto the food web. The phytoextraction risk of the organic pollutants from contaminated soil by herbs requires a thorough study.

As a result of the action of biotic and abiotic factors, the total concentration of chlorinated contaminants added to the soil slowly decreases over time, while it concentrates in the root of Mentha Piperita. The 0.2 value of bioconcentration factor calculated for 4 weeks of monitoring experiment is similar to the results presented in the literature for poplar and zucchini. On the fourth week it was found only PCB 28 in leaves and stem, while congeners 180 and 153 which were predominantly found in the root.

According to the criteria established by environmental agencies, the calculated BCF value is lower than 2000 which means that the uptake of PCBs for 5 weeks in medicinal plant, Mentha Piperita, isn't significant for bioconcentration in this plant cells.

Further investigation could be done in identifying toxic and stable byproducts of PCBs degradation in plants as other PCBs or PCBs derivative.

\section{References}

1. DINU, C., UNGUREANU, E. M., VASILE, G. G., KIM, L., IONESCU, I., ENE, C., SIMION, M., Rev. Chim. (Bucharest), 69, no. 1, 2018, p. 14. 2. STANESCU, B., KIM, L., CUCIUREANU, A., LEHR, C. B., International Symposium The environment and the industry, Proceedings Book, SIMI 2016, p. 112-118.

3. VAN AKEN, B., CORREA, P. A., SCHNOOR, J. L., Environ. Sci. Technol., 15, 44, 8, 2010, p. 2767.

4. PORTA, M, ZUMETA, E.,Implementing the Stockholm Treaty on Persistent Organic Pollutants. Occup. Environ. Med., 59, 2002, p. 651. 5. FIREDMAN, C. L., SELIN, N. E, Atmos. Chem. Phys., 16, 2016, p. 3433.

6. PETRESCU, M., BUCUR, E., DIODIU, R., BRATU, M., SERBANESCU, A., BARBU, M., International Symposium The environment and the industry, Proceedings Book, SIMI 2017, p. 213-220.

7. ANCONA, V., BARRA CARACCIOLO, A., GRENNI, P., DI LENOLA, M., CAMPANALE, C., CALABRESE, A., URICCHIO, V.F., MASCOLO, G., MASSACCI, A., New Biotechnol., 38, B, 2017, p. 65.

8. COZEA, A., BUCUR, E., LEHR, C.B., PASCU, L.F., TANASE, G., Rev. Chim. (Bucharest), 69, no. 11, 2018, p. 3238.

9. JAMES, M.O., SACCO, J.C., FAUX, L.R., Environ. Toxicol. Pharmacol., 25, no. 2, 2008, p. 211.

10. QUINETE, N., ESSER, A., KRAUS, T., SCHETTGEN, T., Toxicol. Lett., 276, 2017, p. 100 
11.*** EFSA, Results of the monitoring of non dioxin-like PCBs in food and feed, EFSA J ournal, 8, no. 7, 2010, 1701, p. 1.

12. WHITFIELD ASLUND, M. L., ZEEB, B. A., RUTTER, A., REIMER, J., Sci. Total Environ., 374, no. 1, 2007, p. 1.

13. TERZAGHI, E., ZANARDINI, E., MOROSINI, C., RASPA, G., BORIN, S., MAPELLI, F., VERGANI, L., DI GUARDO, A., Sci. Total Environ., 612, 2018, p. 544.

14. BORJA, J., TALEON, D. M., AURESENIA, J ,, GALLARDO, S., Process Biochem., 40, 2005, p. 1999.

15. MCKONE, T. E., MADDALENA, R. L., Lawrence Berkeley National Laboratory Report number: LBNL-60273.

16. KAYA, D., KARAKAS, F., SANIN, F. D., IMAMOGLU, I., Water Environ. Res., 87, no. 2, 2015, p. 145.

17. CHIRIAC, L. F., CRUCERU, L., NICULESCU, M., PASCU, L.P., LEHR, C.B., GALAON, T., Rev.Chim. (Bucharest), 68, no. 8, 2017, p. 1685.
18.*** SR ISO 10382/2007 - Calitatea solului. Determinarea pesticidelor organoclorurate si a bifenililor policlorurati. Metoda gaz cromatografica cu detectie prin captura de electroni, 2007.

19. JAVORSKA, H., TLUSTOS, P., KALISZOVA, R., Polish J. of Environ. Stud., 20, no. 1, 2011, p. 99.

20. COCARTA, D.M., ISTRATE, I. A., BULMAU, C., DINU, R., TANASIEV, V., DUMITRESCU, C., Rev. Chim. (Bucharest) 65, no. 1, 2014, p. 49.

21. IONESCU, M., BERANOVA, K., DUDKOVA, V., KOCHANKOVA, L., DEMNEROVA, K., MACEK, T., MACKOVA, M., Int. Biodeterior. Biodegradation, 63, no. 6, 2009, p. 672.

22. KACALKOVA, L., TLUSTOS, P., Cent. Eur. J. Biol., 6, no. 2, 2011, p. 235.

23. MEGGO, R. E., SCHNOOR, J. L., Environ. Sci. (Ruse), 1, no. 1, 2013, p. 52.

24. The Canadian Environmental Protection Act, 1999 (CEPA 1999). 